\title{
sciendo
}

RESEARCH PAPERS FACULTY OF MATERIALS

SCIENCE AND TECHNOLOGY IN TRNAVA

SLOVAK UNIVERSITY OF TECHNOLOGY

IN BRATISLAVA

2021, Volume 29, Number 48

DOI 10.2478/rput-2021-0004

\section{PRELIMINARY BIOLEACHING EXPERIMENT OF E-WASTE}

\author{
Alexandra KUCMANOVÁ ${ }^{1}$, Zuzana SANNY ${ }^{1}$, Kristína GERULOVÁ ${ }^{1}$, \\ Matej PAŠ́́K ${ }^{1}$, Imrich CZÉRE ${ }^{2}$ \\ ${ }^{1}$ SLOVAK UNIVERSITY OF TECHNOLOGY IN BRATISLAVA \\ FACULTY OF MATERIALS SCIENCE AND TECHNOLOGY IN TRNAVA \\ INSTITUTE OF INTEGRATED SAFETY \\ Ulica JÁNA BotTu 2781/25, 91724 TRNAVA, SLOVAK REPUBLIC \\ 2ŽELEZNIČNÉ OPRAVOVNE A STROJÁRNE ZVOLEN, a.s. \\ MÔŤOVSKÁ CESTA 259/11, 96003 ZVOLEN, SLOVAK REPUBLIC \\ e-mail: alexandra.kucmanova@stuba.sk, zuzana.sanny@stuba.sk, kristina.gerulova@stuba.sk, \\ matej.pasak@stuba.sk, czere@zoszv.sk \\ Received 25 April 2021, Accepted 25 May 2021, Published 20 July 2021
}

\begin{abstract}
Nowadays, we can hardly imagine our life without the achievements of modern technology, such as refrigerators, televisions, computers, or smartphones. Producers are pushing consumers to buy newer, more modern appliances instead of repairing the original ones. However, all the devices represent a huge amount of waste. E-waste is one of the fastest growing types of waste, and only less than a half of it is recycled. Its disposal poses a great challenge for the population and constitutes a huge burden for the environment. In the research described in this article, we focused on individual techniques for metals recovery from e-waste. In the experimental part, we deal with the recycling of electronic waste by bioleaching, using microorganisms Acidithiobacillus ferrooxidans and Acidithiobacillus thiooxidans. Compared to conventional techniques, bioleaching is a more environmentally friendly and economical alternative of metals recovery from e-waste.
\end{abstract}

\section{Keywords}

Bioleaching, electronic waste, microorganisms, printed circuit boards

\section{INTRODUCTION}

Technical innovation in the field of electrical and electronic equipment keeps growing rapidly. The industry produces huge amounts of new devices, using newer and better technologies. It forces consumers to change the equipment often. Individual repairs are no longer profitable, and the purchase of newer and more modern equipment becomes more economical. The electronic devices have a short replacement cycle resulting in the exponential growth of electronic waste (e-waste) [1]. As such, it has become one of the fastest-growing 
types of waste. It poses a challenge for waste management, as many electronic products contain both, hazardous and valuable materials [2]. The European Commission has issued the 2002/96/EC Directive, known as the WEEE (Waste Electrical and Electronic Equipment) Directive, with effect from February 13, 2003, with the aim of achieving up to $70-80 \%$ recovery rates of electrical and electronic equipment [3].

\section{ELECTRONIC WASTE}

E-waste is usually referred to as WEEE (Waste Electrical and Electronic Equipment), electronic waste or e-scrap. It includes a wide range of products [4]. The material composition of e-waste depends on its origin, manufacturer, and age. It can be defined as a mixture of various metals, plastics and ceramics [5, 6]. The printed circuit boards (PCBs) are an important [7] and economically attractive component of WEEE [8]. PCBs contain about $28-30 \%$ metallic portion $(10-20 \% \mathrm{Cu}, 1-3 \% \mathrm{Ni}, 1-4 \% \mathrm{Fe}, 1-5 \% \mathrm{~Pb}$, and $0.3-0.4 \%$ of precious metals like $\mathrm{Au}, \mathrm{Ag}$, and $\mathrm{Pt}$ ). The remaining $70 \%$ are non-metallic parts, such as polymers, ceramics, and plastics $[9,10]$. Therefore, the PCBs are considered as secondary metal reserves [11]. The conventional methods available for metal removal from e-waste and PCBs waste are pyrometallurgical and hydrometallurgical techniques [12]. Pyrometallurgical processes use heat treatments like roasting, smelting and hydrometallurgical processes are based on chemical leaching by acids/alkalis [13]. The recycling of e-waste is necessary for both, reducing environmental pollution, saving natural ores and protecting human health [9]. Biohydrometallurgy or bio-metallurgy is a biological method for metal recovery. It is based on the same mechanism of hydrometallurgical process and uses microorganisms for production of reagents to extract metals $[14,15]$ from primary (natural ores) or secondary resources (e-waste, i.e., PCBs) $[11,16,17]$. The recovery of metals via bio-metallurgy includes five different mechanisms - biotransformation, biosorption, bioaccumulation, bioleaching, biomineralization [16].

\section{BIOLEACHING}

Bioleaching, also known as microbial leaching [18], is a specialized biohydrometallurgical process which utilizes either metabolic activities or products of microorganisms [17] under soft operating conditions, i.e. low temperatures and a mild pHs [15]. Bioleaching methods are based on the application of the sulphur compounds oxidizing bacteria and microorganisms. The most commonly used microorganisms in bioleaching are iron- and sulphur-oxidizing chemolithotrophic bacteria (Acidithiobacillus ferrooxidans, $A$. thiooxidans, Leptospirillum ferrooxidans, Ferrobacillus), cyanogenic bacteria (Chromobacterium violaceum), moderately thermophilic bacteria (Sulfobacilllus thermosulfidooxidans, Thermoplasma acidophilum, S. thermosulfidooxidans), heterotrophic bacteria (Sulfolobus, Bacillus, Pseudomonas) and microscopic fungi (Aspergillus niger, A. ficuum and Penicillium simplicissimum) [13, 14, 18, 21, 22, 37, 38, 39, 40, 41].

The bacteria can produce organic acids and complexing agents. The bioleaching has been successfully applied to remove heavy elements from sludge, galvanic slag, electronic scrap and combustion waste $[19,20,21]$. The commonly used commercial bioleaching methods to recover metals from various minerals and ores in an industrial scale include heap bioleaching, dump bioleaching and stirred reactor. Among those operations, the heap bioleaching is currently the most successful technology for the recovery of base metals, which is due to its low cost, simple operation and high yield [22].

Bioleaching can be divided into two main pathways: direct and indirect. The direct pathway is achieved by direct electron transfer from mineral sulphides to microorganism cells (e.g. A. ferrooxidans) [23] at the inoculation stage [24], without the formation of ferrous sulphate. The cells must be tightly attached to the mineral surface. The adhesion of 
microorganisms to the substrate occurs first through the Van der Waals-type forces. The interaction between microorganisms and the mineral is also enhanced by the formation of extracellular compounds produced by bacteria, so-called exopolysaccharides which mainly consist of sugars, lipids, and proteins. Adherent bacteria begin to reproduce and form microcolonies. The colonies cover the material and form a multilayer film - a biofilm [25, 26, 27]. In the indirect pathway, the microorganisms are not directly involved in the mineralization of metals, but they generate solid oxidizing agents [24]. Indirect bioleaching includes three primary methods: C-mediated, S-mediated and Fe-mediated. The $\mathbf{C}$-mediated bioleaching is achieved through the reaction between e-waste and microbial metabolites (e.g., cyanide, citrate and oxalate) produced by microorganisms through carbon metabolism [28]. The S-mediated bioleaching can be achieved through the oxidation of reduced sulphur substances by acidophilic sulphur-oxidizing autotrophs or sulphur- and iron-oxidizing autotrophs to produce $\mathrm{H}_{2} \mathrm{SO}_{4}$ resulting in the acidification of metals from e-waste [27]. In Fe-mediated bioleaching, the oxidation of the reduced metal is caused by ferric ions $\left(\mathrm{Fe}^{3+}\right)$ produced by microbial oxidation of the ferrous ion $\left(\mathrm{Fe}^{2+}\right)$ compounds present in the mineral. Ferric ion $\left(\mathrm{Fe}^{3+}\right)$ acts as an oxidizing agent and can oxidize metal sulphides. It is then chemically reduced to ferrous ion which can be microbially oxidized to the ferric ions again. In that case, iron has a role of an electron carrier [23]. The chemical transformations can be represented by the following simplified equations [5]:

$$
\begin{gathered}
\mathrm{MS}+2 \mathrm{Fe}^{3+} \rightarrow \mathrm{M}^{2+}+2 \mathrm{Fe}^{2+}+\mathrm{S}^{0} \\
2 \mathrm{Fe}^{2+}+1 / 2 \mathrm{O}_{2}+2 \mathrm{H}^{+} \rightarrow 2 \mathrm{Fe}^{3+}+\mathrm{H}_{2} \mathrm{O} .
\end{gathered}
$$

From an industrial point of view, the indirect leaching is more beneficial. Starting the leaching process independently of the abiotic effects offers more flexibility in optimizing the process of metal extraction [25]. Some authors reported that high amounts of different metals [29][30] and organic components present in PCBs have a toxic effect on bioleaching bacteria, thus reducing the leaching efficiency [14]. On the other side, different authors [31, 32] state that $A$. ferrooxidans is a bacteria resistant to high amount of toxins to a certain extent, and can be used for recovery of heavy metals (such as $\mathrm{Ni}, \mathrm{Cd}, \mathrm{Co}$ ) from exhausted batteries.

There are also external factors affecting the successful bioleaching and metabolic activity of microorganisms. Those include, for example $\mathrm{pH}$, concentration of $\mathrm{Fe}^{2+}$, qualitative and quantitative composition of E-waste, the type of grinding material, grinding temperature and grinding time [33, 34], particle size, surface area of bioleached material, prior adaptation of the microorganisms, oxidation - reduction potential (ORP), available $\mathrm{O}_{2}$ and $\mathrm{CO}_{2}$, amount of nutrients and the form in which the metals are present (oxides, sulphides, metallic form) [26].

pH of the leaching medium influences both, leaching biology and chemical reactions. The $\mathrm{pH}$ of the medium has a direct relationship with bacterial growth, and it regulates the metal solubilisation. A majority of metals are recovered at acidic $\mathrm{pH}$ of $2.0-2.5$. A higher $\mathrm{pH}$ decreases the bacteria-mediated oxidation of $\mathrm{Fe}^{2+}$ to $\mathrm{Fe}^{3+}$. A very low $\mathrm{pH}$ slows down the leaching so as the high $\mathrm{pH}$ has an inhibitory effect on the bacterial growth, leading to the low metal solubilisation [13].

Another factor significantly affecting the efficiency of bioleaching and relating to $\mathrm{pH}$ is oxidation reduction potential (ORP). ORP is a parameter indicating the $\mathrm{Fe}^{3+} / \mathrm{Fe}^{2+}$ ratio in the system with a higher concentration of $\mathrm{Fe}^{2+}[8,11]$. There is an indirect relationship between $\mathrm{pH}$ and ORP. When $\mathrm{pH}$ increases, ORP decreases, and vice versa. This has been proven by many researchers $[9,33]$.

The optimal bioleaching temperature depends on the growth requirements of different microorganisms. Most mesophilic acidophiles mobilize metals at the optimal temperature range of $25-30{ }^{\circ} \mathrm{C}$, while thermophiles leach at the optimal temperature of $40-45^{\circ} \mathrm{C}$. Therefore, the 
temperature must be compatible with the active growth and metabolism of the selected bacteria involved in the biological leaching process in order to effectively solubilize the metal [13].

Another important factor affecting successful bioleaching is an appropriate nutrient requirement of the leaching medium. It affects the metal dissolution by arresting the cell growth. The rate of bioleaching of the iron and sulphur-oxidizing bacteria varies with the concentration of $\mathrm{Fe}^{2+}$ and $\mathrm{S}^{0}$. An increase of the $\mathrm{Fe}^{2+}$ concentration in nutrient medium causes precipitation of the $\mathrm{Fe}^{3+}$-forming jarosite which inhibits the bioleaching process [13]. Nazari et al. examined the effect of ferrous iron concentration in the growth medium $(9 \mathrm{~K}), \mathrm{pH}$, and temperature of jarosite formation in the presence of Acidithiobacillus ferrooxidans. They found that the highest amount of jarosite was formed at a ferrous sulphate concentration of $50 \mathrm{~g} \mathrm{~L}^{-1}$ at $32{ }^{\circ} \mathrm{C}$ and an initial $\mathrm{pH}$ of 2.2 [35]. Jin-yan et al. studied the effect of Thiobacillus ferrooxidans on the oxidation of metal sulphide and the formation of jarosite. The minimal jarosite precipitates $\left(3.73 \mathrm{~g} \mathrm{~L}^{-1}\right)$ and the good growing activity of bacteria was at the initial $\mathrm{pH}$ of $1.6-1.7$ with the $\mathrm{Fe}^{2+}$ concentration of $9-10 \mathrm{~g} \mathrm{~L}^{-1}$, and the applied potential of $-0.5 \mathrm{~V}$ for 7 hours [36]. To assess the success of bioleaching, it is important to measure the $\mathrm{Fe}^{3+}$ and $\mathrm{Fe}^{2+}$ concentrations [31].

The aim of our experiment was to perform the bioleaching of selected E-waste using acidophilic bacterial strains, and to verify the ability of bacterial strains to speed up the dissolution of metals into solution.

\section{MATERIALS AND METHODOLOGY}

\section{Adapted bacterial strains}

Based on literature [30, 42, 43], we performed a two-step bioleaching. For the bioleaching experiments, an adapted culture of $A$. ferrooxidans and a nonadapted culture of $A$. thiooxidans were used. The adaptation process was taken 5 days in the presence of the same electronic waste sample as it was used in the experiment. Bacteria were predominantly cultivated in a sterile $9 \mathrm{~K}$ culture medium which contained ferrous sulphate (44.22 $\mathrm{g} \mathrm{L}^{-1}$, as the energy source), $\left(\mathrm{NH}_{4}\right)_{2} \mathrm{SO}_{4}\left(3.0 \mathrm{~g} \mathrm{~L}^{-1}\right), \mathrm{MgSO}_{4}\left(0.5 \mathrm{~g} \mathrm{~L}^{-1}\right), \mathrm{K}_{2} \mathrm{HPO}_{4}\left(0.5 \mathrm{~g} \mathrm{~L}^{-1}\right), \mathrm{KCl}\left(0.1 \mathrm{~g} \mathrm{~L}^{-1}\right)$ and $\mathrm{Ca}\left(\mathrm{NO}_{3}\right)_{2}$ $\left(0.01 \mathrm{~g} \mathrm{~L}^{-1}\right)$. Both cultures of nonadapted microorganisms were obtained from the Department of Mineral Biotechnology of the Slovak Academy of Sciences in Košice.

\section{Experimental design of bioleaching}

The electronic waste samples used in the experiment are shown in Figure 1. The samples were pre-treated in a saturated solution of $\mathrm{NaOH}$ and $\mathrm{KOH}$ to remove protective coating. In total, $400 \mathrm{~mL}$ of $9 \mathrm{~K}$ culture medium with the inoculum (mixed bacteria of A. ferrooxidans and A. thiooxidans 1:1) were transferred into a $500 \mathrm{~mL}$ Erlenmeyer flask and cultivated under constant temperature $(30 \pm 1){ }^{\circ} \mathrm{C}$. The inoculum was used at three different concentrations $(10 \%, 15 \%$ and $25 \%$ (vol.)). The control sample did not contain any inoculum. The pH during the bioleaching or the adaptation (measured with WTW Multi 340i) was maintained in the range of 1.8-2.0 by the addition of $\mathrm{H}_{2} \mathrm{SO}_{4}$. An oxidation reduction potential (ORP) was measured by a maintenance-free SenTix ${ }^{\circledR P t R}$ redox combination electrode (WTW Multi 340i). The suspension was stirred constantly at $160 \mathrm{r} \mathrm{min}^{-1}$ and continuously aerated. The aeration was provided by an ALITA Air Pump AL-6SA using a glass pipette. Prior to injection, the air was purified on a Millex-FG 50mm PTFE air filter with a pore size of $2 \mu \mathrm{m}$. The aeration was used only in the bioleaching experiment itself. The electronic waste samples were analysed under a microscope at baseline and after 0, 48, 96 and 120 hours. The total experiment duration was 120 hours. 
a)

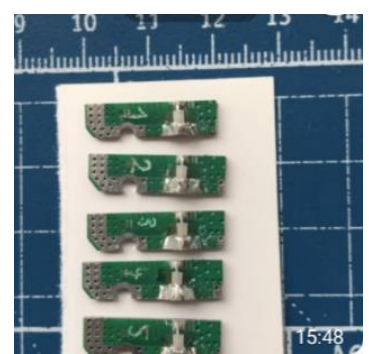

b)

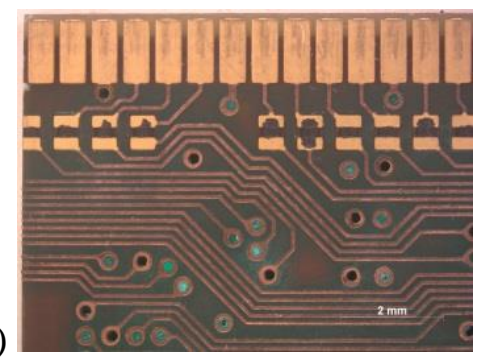

c)

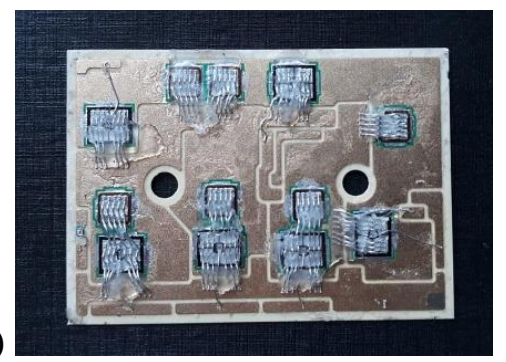

Figure 1 Samples $(a, b, c)$ of untreated electronic waste used in the experiment of bioleaching

\section{RESULTS AND DISCUSSION}

Figures 2-4 document the e-waste after bioleaching process with and without the presence of bacteria (control). Cross-section of the e-waste samples is provided in Figure 2, and top views are given in Figures 3 (an overview) and 4 (detail). As can be seen, the bioleaching in the presence of bacteria was faster; it helped to transfer the metals from electronic waste into solution more efficiently compared to the control sample.

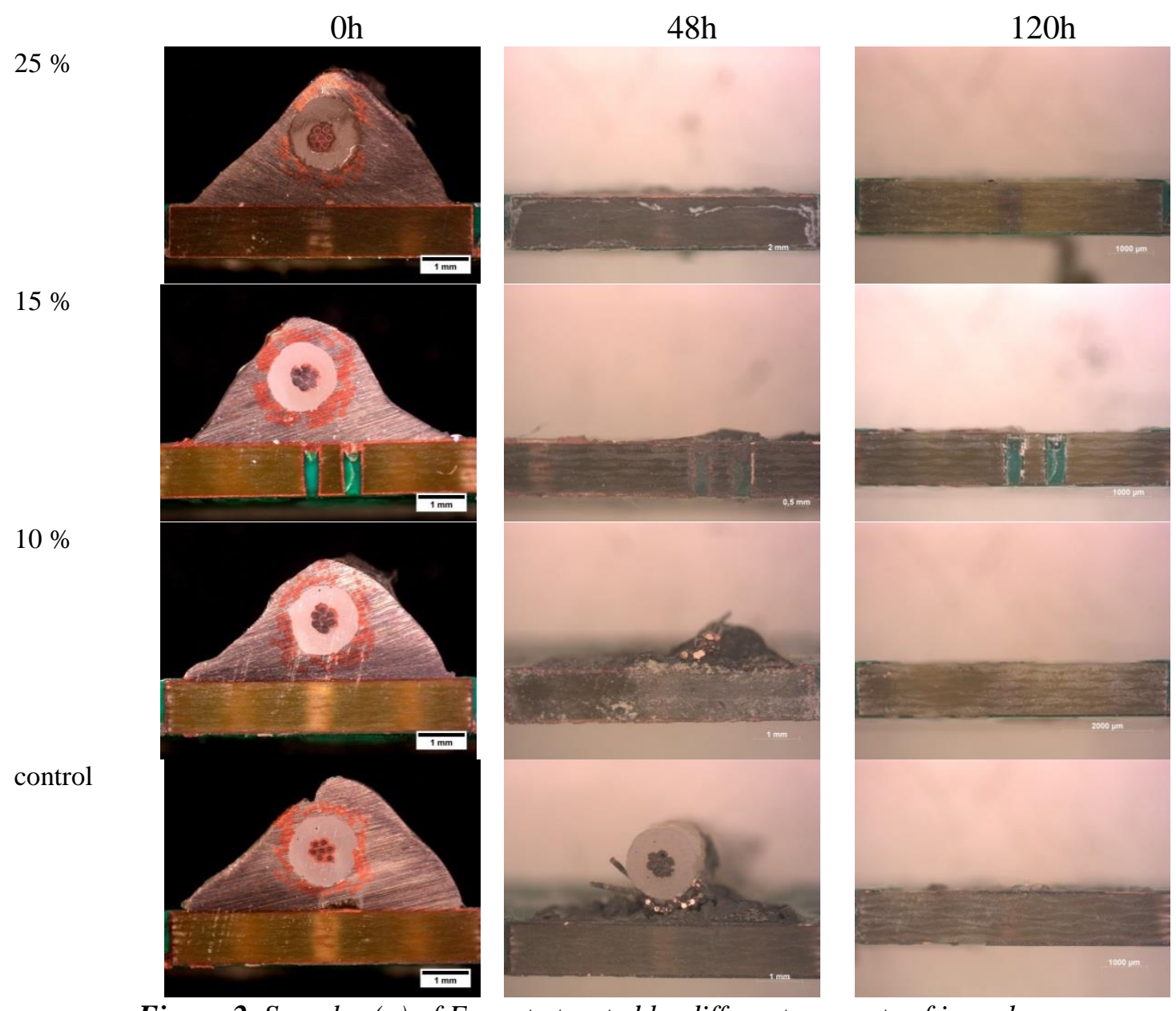

Figure 2 Samples (a) of E-waste treated by different amounts of inoculum 


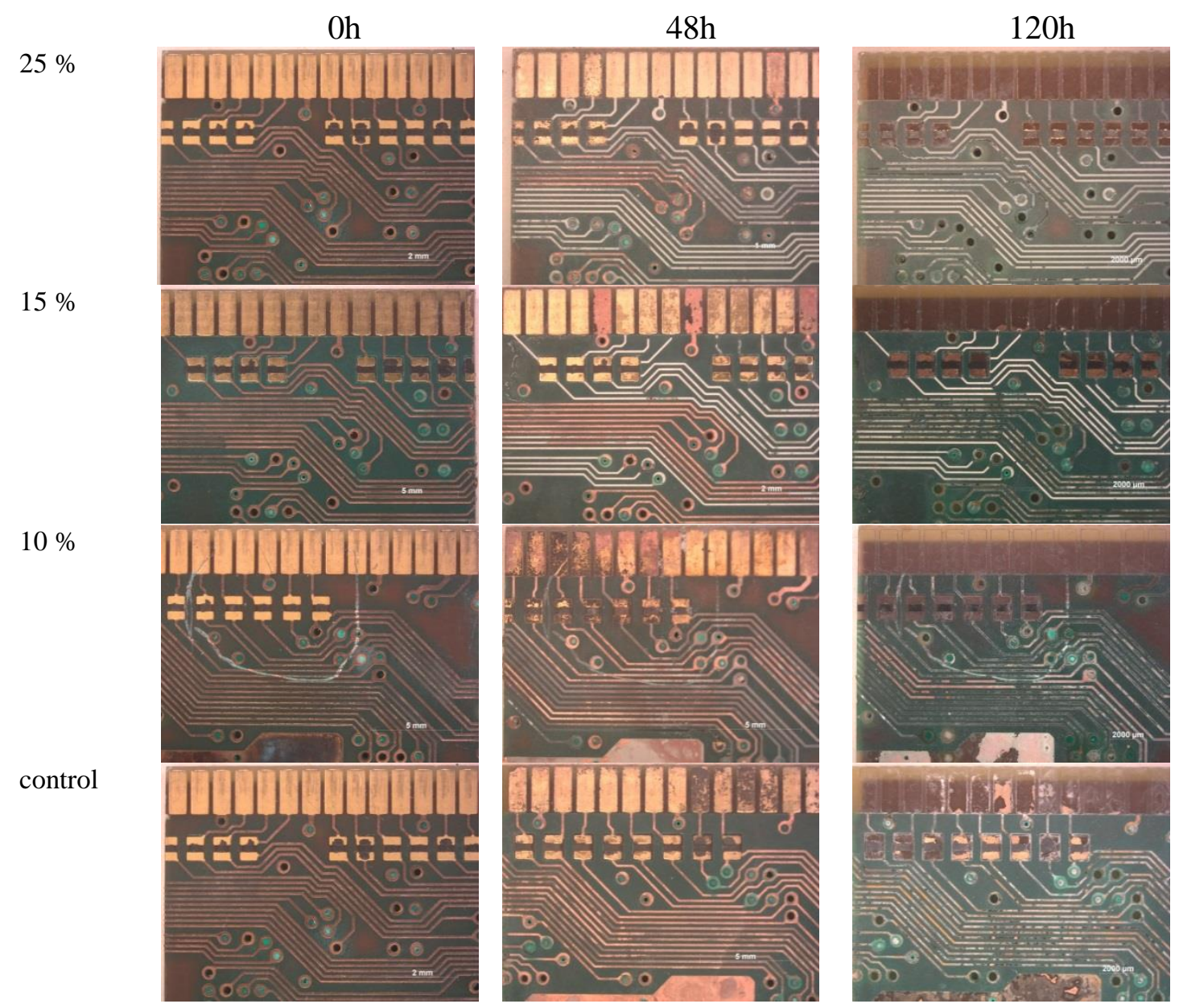

Figure 3 Samples (b) of E-waste treated by different amounts of inoculum

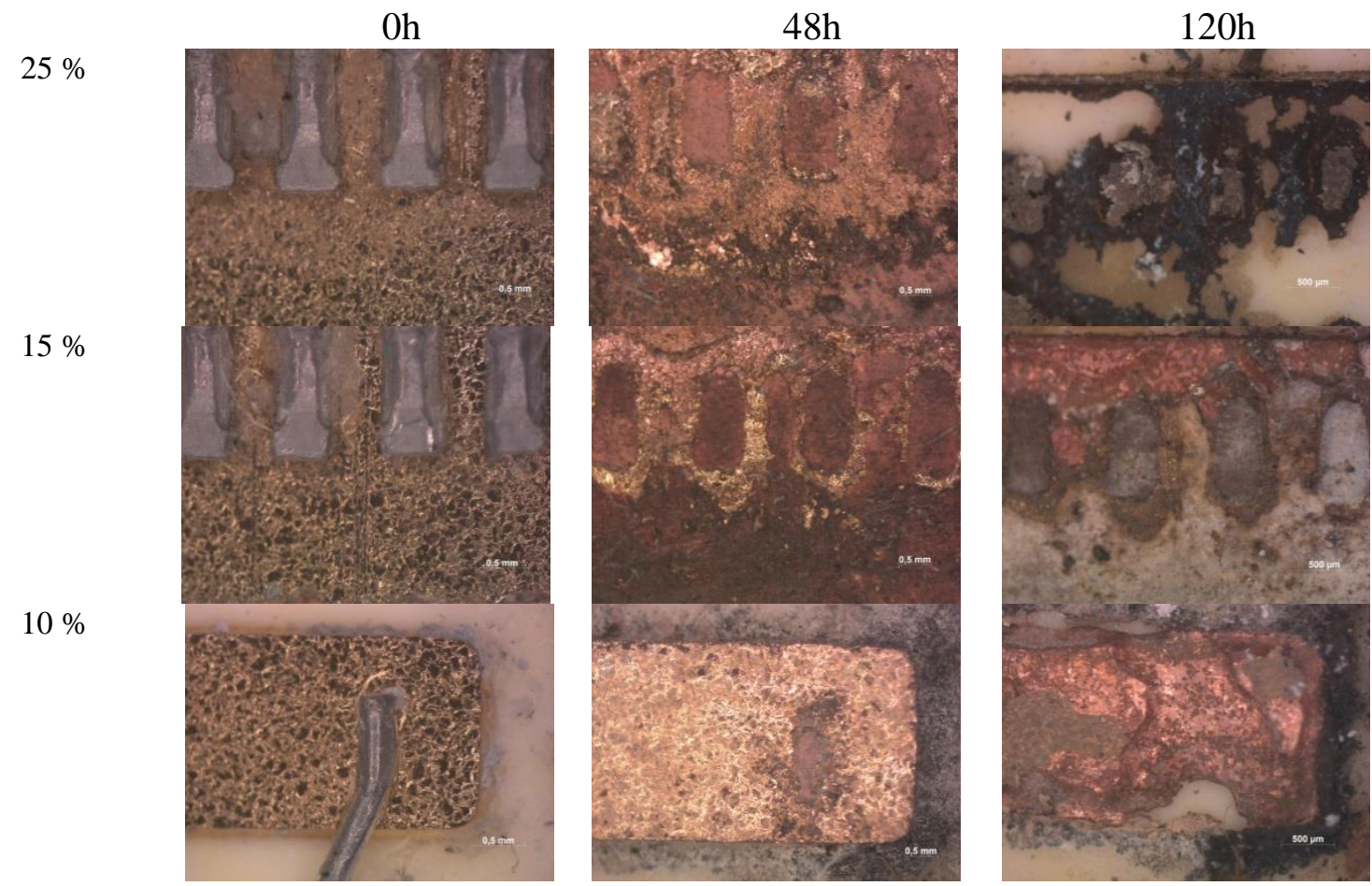


control
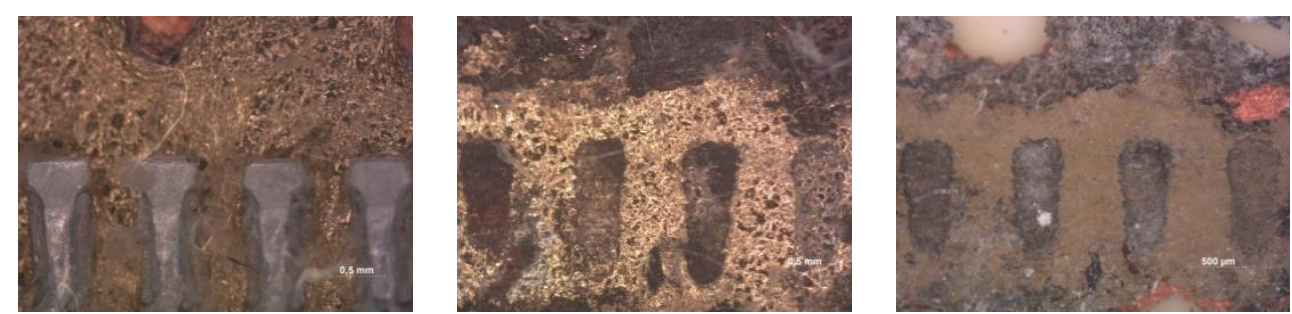

Figure 4 Samples (c) of E-waste treated by different amounts of inoculum

Despite a regular measurement and adjustment to the desired value with sulfuric acid, $\mathbf{p H}$ slightly increased (Figure 5). The $\mathrm{pH}$ factor of solution is very important, as it usually controls the bacterial growth. According to Jin-yan et al. [36], $\mathrm{pH}$ affects the amount of jarosite precipitated and rate of bacterial growth. The bio-oxidation of $\mathrm{Fe}^{2+}$ could have consumed protons from the solution, which was accompanied by an increase of $\mathrm{pH}[44,45]$. The $\mathrm{pH}$ increase promoted a ferric ion formation and jarosite precipitation. It resulted in the inhibition of the bacteria-mediated iron oxidation owing to the formation of a precipitate layer around the bacterial cells [17].

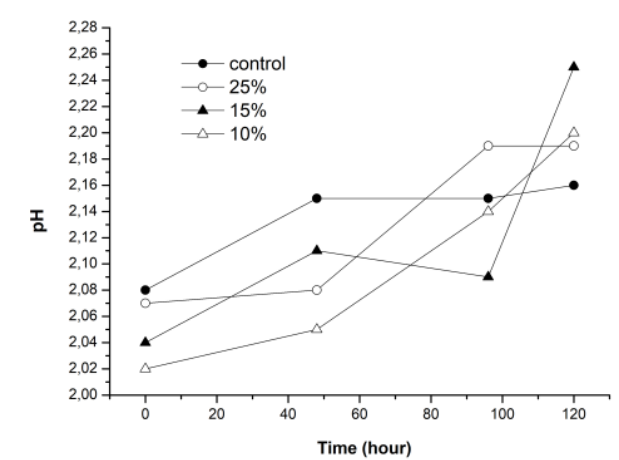

Figure 5 pH kinetics during the experiment

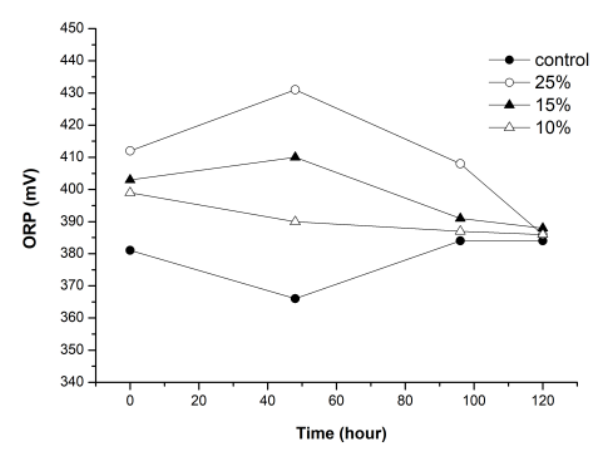

Figure 6 Oxidation reduction potential kinetics during the experiment

An increase of ORP, given in Figure 6, reflected the activity of microorganisms. It indicates that the leaching is promoted by bacteria and there was a bacterial oxidation and regeneration of $\mathrm{Fe}^{2+}$ to $\mathrm{Fe}^{3+}$ [34]. The ORP began to decrease in the samples with high concentration of inoculum after 48 hours. Similar results were also published in reference [9]. Willner [33] states that the decrease of ORP at the end of the process indicates a regressive phase of bioleaching and slows down the activity of bacteria in solutions.

After the inoculum adaptation process, it is recommended to centrifugate the bacteria from the cultivation solution. For better assessment of the conditions during bioleaching, it is also recommended to evaluate the level of $\mathrm{Fe}^{2+}$ and $\mathrm{Fe}^{3+}$ in the solution.

\section{CONCLUSION}

In the experiment described in this article, we investigated the possibility of e-waste recycling by bioleaching aided by Acidithiobacillus ferrooxidans and Acidithiobacillus thiooxidans. Bioleaching is a more environmentally friendly and economical alternative to metals recovery, compared to conventional techniques. We observed a higher rate of metal leaching into the solution in presence of inoculum. The leaching started with Al solder and continued with $\mathrm{Cu}$ substrate. An increase of ORP reflected the growth activity of microorganisms. It indicated that leaching is promoted by bacteria, and there was a bacterial 
oxidation and regeneration of $\mathrm{Fe}^{2+}$ to $\mathrm{Fe}^{3+}$. Determination of the exact metal concentrations in solution is a task for future experiments.

\section{Acknowledgement}

The article was written with the support of the Project of KEGA Grant Agency of the Ministry of Education, Science, Research and Sport of the Slovak Republic No. 020STU-4/2021: Building an innovative teaching laboratory for practical and dynamic education of students in the field of occupational safety and health.

\section{References}

[1] SODHA, A. B., TIPRE, D. R., DAVE, S. R. 2020. Optimisation of biohydrometallurgical batch reactor process for copper extraction and recovery from non-pulverized waste printed circuit boards. Hydrometallurgy, 191, 1-9. ISSN 0304386X.

[2] FORTI, V., BALDÉ, C. P., KUEHR, R. 2018. E-waste Statistics: Guidelines on classification, reporting and indicators. 2nd edition. Bonn: United Nations University, ViE - SCYCLE, Bonn, Germany. 2018. 37 p. ISBN 978-92-808-9067-9.

[3] NING, C., LIN, C. S. K., HUI, D. C. W., McKAY, G. 2017. Waste Printed Circuit Board (PCB) Recycling Techniques. Top. Curr. Chem., 375(2), 1-36. ISSN 03401022.

[4] BALDÉ, C. P., FORTI, V., GRAY, V., KUEHR, R., STEGMANN, P. 2017. The global e-waste monitor - 2017. Bonn/Geneva/Vienna: United Nations University (UNU), International Telecommunication Union (ITU) \& International Solid Waste Association (ISWA), Bonn/Geneva/Vienna, 2017. 116 p. ISBN 978-92-808-9054-9.

[5] CUI. J., ZHANG, L. 2008. Metallurgical recovery of metals from electronic waste: A review. $J$. Hazard. Mater., 158(2-3), 228-256. ISSN 03043894.

[6] ILYAS, S., LEE, J., CHI, R. 2013. Bioleaching of metals from electronic scrap and its potential for commercial exploitation. Hydrometallurgy, 131-132, 138-143. ISSN 0304-386X.

[7] ARSHADI, M., MOUSAVI, S. M. 2014. Simultaneous recovery of Ni and Cu from computerprinted circuit boards using bioleaching: Statistical evaluation and optimization. Bioresour. Technol., 174, 233-242. ISSN 18732976.

[8] AKBARI, S., AHMADI, A. 2019. Recovery of copper from a mixture of printed circuit boards (PCBs) and sulphidic tailings using bioleaching and solvent extraction processes. Chem. Eng. Process. - Process Intensif., 142, 1-8. ISSN 02552701.

[9] ARSHADI M., YAGHMAEI, S. 2020. Advances in bioleaching of copper and nickel from electronic waste using Acidithiobacillus ferrooxidans: evaluating daily $\mathrm{pH}$ adjustment. Chem. Pap., 74, 2211-2227. ISSN 1336-9075.

[10] AN, J. 2021. Characteristics of metals leached from waste printed circuit boards using acidithiobacillus ferrooxidans. Minerals, 11(2), 1-8. ISSN 2075163X.

[11] KANAUJIA, K., HAIT, S. 2021. Improved Sequential Approachfor Hybrid Bioleaching of Metals from E-Waste. In: S. Kumar et al. Sustainability in Environmental Engineering and Science. Eds. Springer Singapore, 2021. pp. 113-120. ISBN 9789811568879.

[12] PRIYA, A., HAIT, S. 2020. Biometallurgical recovery of metals from waste printed circuit boards using pure and mixed strains of Acidithiobacillus ferrooxidans and Acidiphilium acidophilum. Process Saf. Environ. Prot., 143, 262-272. ISSN 0957-5820.

[13] PRIYA, A. HAIT, S. 2017. Comparative assessment of metallurgical recovery of metals from electronic waste with special emphasis on bioleaching. Environ. Sci. Pollut. Res., 24(8), 69897008. ISSN 16147499.

[14] BANIASADI, M., VAKILCHAP, F., BAHALOO-HOREH, N., MOUSAVI, S. M., FARNAUD, S. 2019. Advances in bioleaching as a sustainable method for metal recovery from e-waste: A review. J. Ind. Eng. Chem., 76, 75-90. ISSN 1226-086X.

[15] HUBAU, A., MINIER, M., CHAGNES, A., JOULIAN, C., SILVENTE, C., GUEZENNEC, A. G. 2020. Recovery of metals in a double-stage continuous bioreactor for acidic bioleaching of printed circuit boards (PCBs). Sep. Purif. Technol., 238, 1-16. ISSN 18733794. 
[16] AWASTHI, A. K., HASAN, M. et al. 2019. Environmentally sound system for E-waste: Biotechnological perspectives. Curr. Res. Biotechnol., 1, 58-64. ISSN 2590-2628.

[17] MRÁŽIKOVÁ, A., KADUKOVÁ, J., MARCINČÁKOVÁ, R. et al. 2016. The Effect of Specific Conditions on $\mathrm{Cu}, \mathrm{Ni}, \mathrm{Zn}$ and $\mathrm{Al}$ Recovery from PCBS Waste Using Acidophilic Bacterial Strains. Arch. Metall. Mater., 61(1), 261-264. ISSN 1733-3490.

[18] CHEN, S., YANG, Y., LIU, C., DONG, F., LIU, B. 2015. Column bioleaching copper and its kinetics of waste printed circuit boards (WPCBs) by Acidithiobacillus ferrooxidans. Chemosphere, 141, 162-168. ISSN 18791298.

[19] KARWOWSKA, E., WOJTKOWSKA, M., ANDRZEJEWSKA, D. 2015. The influence of metal speciation in combustion waste on the efficiency of $\mathrm{Cu}, \mathrm{Pb}, \mathrm{Zn}, \mathrm{Cd}, \mathrm{Ni}$ and $\mathrm{Cr}$ bioleaching in a mixed culture of sulfur-oxidizing and biosurfactant-producing bacteria. J. Hazard. Mater., 299, 3541. ISSN 18733336.

[20] LIANG, G., MO, Y., ZHOU, Q. 2010. Novel strategies of bioleaching metals from printed circuit boards (PCBs) in mixed cultivation of two acidophiles. Enzyme Microb. Technol., 47(7), 322-326. ISSN 01410229.

[21] MIKODA, B., POTYSZ, A., KMIECIK, E. 2019. Bacterial leaching of critical metal values from Polish copper metallurgical slags using Acidithiobacillus thiooxidans. J. Environ. Manage., 236, 436-445. ISSN 10958630.

[22] PATHAK, A., SRICHANDAN, H., KIM, D. J. 2019. Column bioleaching of metals from refinery spent catalyst by Acidithiobacillus thiooxidans: Effect of operational modifications on metal extraction, metal precipitation, and bacterial attachment. J. Environ. Manage., 242, 372-383. ISSN 10958630.

[23] MAHMOUD, A., CÉZAC, P., HOADLEY, A. F. A., CONTAMINE, F., D'HUGUES, P. 2017. A review of sulfide minerals microbially assisted leaching in stirred tank reactors. Int. Biodeterior. Biodegrad., 119, 118-146. ISSN 09648305.

[24] PANT, D., DHIMAN, V. 2020. An overview on environmental pollution caused by heavy metals released from e - waste and their bioleaching. In: Advances in Environmental Pollution Management: Wastewater Impacts and Treatment Technologies, 1st ed. P. Kumar, V., Kamboj, N., Payum, T., Singh, J. and Kumar, Ed. pp. 41-53. ISBN 978-81-942017-4-8.

[25] VALIX, M. 2017. Bioleaching of Electronic Waste: Milestones and Challenges. In: Current Developments in Biotechnology and Bioengineering: Solid Waste Management. Elsevier B.V. 2017. 504 p. ISBN 978-0-444-63664-5.

[26] SILVAS, F. P. C., ESPINOSA, D. C. R., TENÓRIO, J. A. S. 2015. Bioleaching. In: Electronic Waste: Recycling Techniques, H. M. Veit and A. M. Bernades, Eds. Springer International Publishing Switzerland. 2015, 159 p. ISBN 9783319157146.

[27] ZHAO, F. WANG, S. 2019. Bioleaching of electronic waste using extreme acidophiles. In: Electronic Waste Management and Treatment Technology. Elsevier Inc. 2019. 363 p. ISBN 9780128161906.

[28] Wang, S., Zheng, Y., Yan, W., Chen, L., Mahadevan, G. D., Zhao, F. 2016. Enhanced bioleaching efficiency of metals from E-wastes driven by biochar. J. Hazard. Mater., 320, 393-400. ISSN 18733336.

[29] BRYAN, C. G., WATKIN, E. L., MCCREDDEN, T. J., WONG, Z. R., HARRISON, S. T. L., KAKSONEN, A. H. 2015. The use of pyrite as a source of lixiviant in the bioleaching of electronic waste. Hydrometallurgy, 152, 33-43. ISSN 0304386X.

[30] BRANDL, H., BOSSHARD, R., WEGMANN, M. 2001. Computer-munching microbes: Metal leaching from electronic scrap by bacteria and fungi. Hydrometallurgy, 59, 319-326. ISSN 15724409.

[31] IJADI BAJESTANI, M., MOUSAVI, S. M., SHOJAOSADATI, S. A. Bioleaching of heavy metals from spent household batteries using Acidithiobacillus ferrooxidans: Statistical evaluation and optimization. Separation and Purification Technology, 132, 309-316. ISSN 13835866.

[32] MRAŽÍKOVÁ, A., MARCINČÁKOVÁ, R., KADUKOVÁ, J., VELGOSOVÁ, O. 2013. Influence of bacterial culture to copper bioleaching from printed circuit boards. Inzynieria Mineralna, 14(2), 59-62. ISSN 16404920.

[33] WILLNER, J. 2013. Influence of physical and chemical factors on biological leaching process of copper from printed circuit boards, Metalurgija, 52(2), 189-192. ISSN 05435846. 
[34] WILLNER, J. FORNALCZYK, A. 2013. Extraction of metals from electronic waste by bacterial leaching. Environ. Prot. Eng., 39(1), 197-208. ISSN 03248828.

[35] B. NAZARI, E. JORJANI, H. HANI, Z. MANAFI, AND A. RIAHI. 2014. Formation of jarosite and its effect on important ions for Acidithiobacillus ferrooxidans bacteria. Trans. Nonferrous Met. Soc. China (English Ed., vol. 24, no. 4, pp. 1152-1160.

[36] JIN-YAN, L., XIU-XIANG, T., PEI, C. 2009. Study of formation of jarosite mediated by Thiobacillus ferrooxidans in 9K medium. Procedia Earth Planet. Sci., 1(1), 706-712. ISSN 18785220.

[37] ILYAS, S., RUAN, C., BHATTI, H. N., GHAURI, M. A., ANWAR, M. A. 2010. Column bioleaching of metals from electronic scrap. Hydrometallurgy, 101(3-4), 135-140. ISSN 0304386X.

[38] WU, W., LIU, X., ZHANG, X., ZHU, M., TAN, W. 2018. Bioleaching of copper from waste printed circuit boards by bacteria-free cultural supernatant of iron-sulfur-oxidizing bacteria. Bioresources and Bioprocesses, 5(1), 1-13. ISSN 21974365.

[39] IŞILDAR, A. et al. 2019. Biotechnological strategies for the recovery of valuable and critical raw materials from waste electrical and electronic equipment (WEEE) - A review. J. Hazard. Mater., 362, 467-481. ISSN 18792456.

[40] WU, H. Y., TING, Y. P. 2006. Metal extraction from municipal solid waste (MSW) incinerator fly ash - Chemical leaching and fungal bioleaching. Enzyme Microb. Technol., 38(6), 839-847. ISSN 01410229.

[41] ABHILASH, TABASSUM, S., GHOSH, A., MESHRAM, P., VAN HULLEBUSCH, E. D. 2021. Microbial Processing of Waste Shredded PCBs for Copper Extraction Cum SeparationComparing the Efficacy of Bacterial and Fungal Leaching Kinetics and Yields. Metals, 11(2), 117. ISSN 20754701.

[42] MÄKINEN, J., BACHÉR, J., KAARTINEN, T., WAHLSTRÖM, M., SALMINEN, J. 2015. The effect of flotation and parameters for bioleaching of printed circuit boards. Miner. Eng., 75, 26-31. ISSN 08926875.

[43] ZHANG, S., YAN, L., XING, W., CHEN, P., ZHANG, Y., WANG, W. 2018. Acidithiobacillus ferrooxidans and its potential application. Extremophiles, 22(4), 563-579. ISSN 14334909.

[44] ZHU, N., XIANG, Y., ZHANG, T. ET AL. 2011. Bioleaching of metal concentrates of waste printed circuit boards by mixed culture of acidophilic bacteria. Journal of Hazardous Materials, 192(2), 614-619. ISSN 03043894.

[45] NIE, H., YANG, CH., ZHU, N., WU, P. et al. 2015. Isolation of Acidithiobacillus ferrooxidans strain Z1 and its mechanism of bioleaching copper from waste printed circuit boards. Journal of Chemical Technology and Biotechnology, 90(4), 714-721. ISSN 10974660.

\section{ORCID}

$\begin{array}{ll}\text { Alexandra Kucmanová } & 0000-0003-3089-7712 \\ \text { Zuzana Sanny } & 0000-0003-2079-4277 \\ \text { Kristína Gerulová } & 0000-0003-2588-8627 \\ \text { Matej Pašák } & 0000-0001-8342-3727\end{array}$

